\title{
The effect of fumigation on nematode communities in California almond orchards
}

\author{
Amanda K. Hodson ${ }^{1, *}$, Janina Milkereit ${ }^{1}$, Gavin C. JohN ${ }^{1}$, David A. Doll ${ }^{2}$ and \\ Roger A. DUNCAN ${ }^{3}$ \\ ${ }^{1}$ UC Davis Department of Entomology and Nematology, University of California Davis, One Shields Ave, \\ Davis, CA 95616, USA \\ ${ }^{2}$ University of California Cooperative Extension, 2145 W. Wardrobe Avenue, Merced, CA 95340, USA \\ ${ }^{3}$ University of California Cooperative Extension, 3800 Cornucopia Way, Suite A, Modesto, CA 95358, USA
}

Received: 18 January 2019; revised: 28 March 2019

Accepted for publication: 29 March 2019; available online: 21 May 2019

\begin{abstract}
Summary - Fumigants, such as 1,3-dichloropropene and chloropicrin, have become key to pre-plant pest management in almond production. Whilst the use of these fumigants has become increasingly restricted due to human health concerns, less is known about their below-ground non-target effects in orchards and how nematode communities recover from fumigation over time. In this study, replicated trials compared 1,3-dichloropropene + chloropicrin to non-treated controls in two almond orchards in California, USA. Nematode communities, nematode indices and nematode metabolic footprints were quantified soon after fumigation and for 2 years afterwards. Fumigation reduced the Herbivore Metabolic Footprint in year 1, and populations of Pratylenchus vulnus in year 3. Fumigation also reduced populations of larger omnivores and predators, resulting in lower levels of the Structure Index at one site. Populations of fungalfeeding nematodes were more adversely affected by fumigation than bacterial-feeding nematode populations. At both sites, fumigation still influenced nematode community composition 2 years after treatment application.
\end{abstract}

Keywords - 1,3-dichloropropene, bioindicators, chloropicrin, Meloidogyne, Mesocriconema xenoplax, nematode populations, nontarget fauna, Pratylenchus vulnus, Prunus dulcis, soil food web, USA.

Almond (Prunus dulcis) production relies on pre-plant soil fumigation to control plant-parasitic nematodes and other diseases (Browne et al., 2006). There are three main nematodes of concern in almonds (Micke, 1996): rootknot nematode (Meloidogyne spp.), ring nematode (Mesocriconema xenoplax) and root-lesion nematode (Pratylenchus vulnus). During feeding, these nematodes damage the root system, reducing the uptake of water and nutrients, resulting in stunted trees with reduced yield (Micke, 1996). Since the phase-out of the commonly used fumigant methyl bromide, due to its depleting effects on ozone levels, 1,3-dichloropropene (1,3-D) has been increasingly used as a non-greenhouse gas-emitting alternative (Ibekwe, 2004; Small, 2008). It is commonly combined with $35 \%$ chloropicrin under the trade name Telone $\mathrm{C}-35^{\odot}$. Although 1,3-D has been one of the most widely used fumigants since 1970, recently California has restricted annual applications due to public health concerns (Marks, 2016). Compounding the problem, the effects of fumigation are often influenced by site factors such as soil texture, moisture and organic matter content (Lembright, 1990; Collins et al., 2006). To manage pests better and to understand potential non-target effects, more information is needed on how fumigants interact with soil factors to influence nematode communities.

Nematodes serve as useful indicators of soil ecosystem functioning and soil food web responses to disturbances, such as fumigation (Bongers, 1990; Ettema, 1998; Bongers \& Ferris, 1999; Ekschmitt et al., 2001). Since nematodes are primary and intermediate consumers in soil food webs, the abundances of their feeding guilds reflect those of primary decomposers, such as bacteria and fungi (Ferris \& Matute, 2003). Due to their permeable cuticle, nematodes are in direct contact with soil pollutants and are considered suitable bio-indicators in agricultural systems (Yeates et al., 1991; Neher, 2001; Biagini \& Zullini, 2008). The sensitivity of nematode communities to disturbance can be explained by differences in their life his-

*Corresponding author, e-mail: akhodson@ucdavis.edu 
tory strategies, which can be classified along a coloniserpersister (Cp) scale (Bongers, 1990; Bongers \& Ferris, 1999).

Nematode indices integrate the relative abundances of nematode groups, their feeding habits, and positions on the $\mathrm{Cp}$-spectrum. For example, communities with more predators and omnivores with higher $\mathrm{Cp}$ values will tend to have higher values of the Maturity Index (MI), which reflects the successional stage of the nematode community (Ettema \& Bongers, 1993) and the Structure Index, which estimates food web complexity (Ferris et al., 2001). Nematode communities with greater abundance of opportunistic nematodes with low $\mathrm{Cp}$ values will tend to have higher values of the Enrichment Index (EI), which indicates the level of responsiveness of the food web to increased available resources, including the activity of primary detrital consumers. (Ferris et al., 2001). The Channel Index is determined by the relative quantities of bacterial grazing and fungal grazing nematodes, in $\mathrm{Cp}-1$ and $\mathrm{Cp}-2$ groups, respectively, which gives insight into whether decomposition is proceeding more through bacterial or fungal channels and how management may differentially affect these groups (Ferris et al., 2001).

Fumigation can cause dramatic shifts in nematode communities. In another cropping system, strawberries, applying 1,3-D and chloropicrin reduced fungal-feeding nematodes and increased opportunistic bacterial-feeding nematodes, although the total number of microbial-feeding nematodes remained unchanged (Sánchez-Moreno et al., 2010). Since soil fungal populations are more vulnerable to fumigation than bacterial communities (Stromberger $e t$ al., 2005), these shifts may have resulted from changes in the nematodes food resources. Higher trophic level nematodes, which also have high $\mathrm{Cp}$ values, are often negatively influenced by fumigation, but may be able to recover after a year or more (Sánchez-Moreno et al., 2010; Timper et al., 2012). Other studies found that the effects of soil fumigation on soil organisms, including non-target nematodes, varied with soil texture (Collins et al., 2006) and that the application of organic amendments can alleviate the effects of soil fumigation on soil microbial communities (Dungan et al., 2003).

The current study compared nematode communities from two experimental almond orchards where fumigation was applied. We hypothesised that fumigation would reduce nematode community structure and that fungalfeeding nematodes would be more adversely affected by fumigation than bacterial-feeding nematodes. Greater understanding of how fumigation influences orchard nema- tode communities could lead to better pest management and understanding of non-target effects.

\section{Materials and methods}

\section{EXPERIMENTAL DESIGN}

To characterise how soil communities responded to fumigation in almonds, experiments were set up in two orchards on sandy loam soils known to be infested with root-knot (Meloidogyne spp.), root-lesion (P. vulnus) and ring (M. xenoplax) nematodes. The first experiment was located in Merced County, CA, USA, near the town of Ballico and the second experiment in Stanislaus County, CA, USA, near the city of Modesto. Hereafter, the two sites are simply referred to as Merced and Stanislaus after the counties where they were located. While the previous crop at Merced was almond on 'Nemaguard' rootstock, the Stanislaus site followed two generations of peach orchards that spanned 40 years or more. At both sites, the previous orchard was removed mechanically in the autumn of 2014 and the soil ripped 0.9-1.2 m deep to remove remaining roots and break up hardpan. All plots remained fallow from the autumn of 2014 to the spring of 2015. In the spring of 2015, almonds were replanted at both sites with 'Nemaguard' almond rootstocks grafted to the scion 'Nonpareil'. The spacing of almonds was $4.9 \times 6.7 \mathrm{~m}$ at Merced and $4.9 \times 6.6 \mathrm{~m}$ at Stanislaus. Almonds were irrigated at Merced by a double inline drip tube and at Stanislaus by microsprinklers. Almonds were planted either in non-fumigated soil, or soil that had been fumigated in the autumn of 2014 with 1,3 dichloropropene (1,3-D):chloropicrin 63:35, which was applied at a rate of $600 \mathrm{~kg} \mathrm{ha}^{-1}$ using a $3.6 \mathrm{~m}$ wide rig centred on the tree row according to standard practice. The randomised complete block design comprised five blocks of 12 trees. Within each block, two plots were created, each of six trees, with one plot treated with fumigant, while the remaining plot was maintained as a non-fumigated control (for a total of ten experimental plots for each site).

\section{SOIL SAMPLING, NEMATODE EXTRACTION AND IDENTIFICATION}

Sampling focused on the raised berm where almond trees were planted. This area was treated with a combination of pre-plant and post-plant herbicides annually and remained weed free for the summer and autumn during the experiment. Nematode samples were collected in 
mid-October of each year and followed a protocol similar to Shurtleff \& Averre (2000), with the first sampling taking place after fumigation but before tree planting in 2014. For each of the ten plots, four soil cores $(25.4 \mathrm{~mm}$ diam., $45.7 \mathrm{~cm}$ depth) were taken from within the dripline of each of four trees and pooled for analysis, for a total of ten samples at each site (five fumigated and five controls). Nematodes were extracted from $200 \mathrm{ml}$ of moist field soil using a sieving and decanting technique followed by sugar centrifugation (Barker, 1984) with an extraction efficiency of $\mathrm{ca} 64 \%$. The total number of nematodes in each sample was counted, and the first 200 encountered on a slide were identified. Most nematodes were identified to the genus level according to Bongers (1988) and feeding classifications and functional guilds assigned according to Yeates et al. (1993) and Bongers \& Bongers (1998). The abundances were scaled to nematodes $(1 \text { soil })^{-1}$ and used to calculate nematode indices of ecosystem function such as the Channel, Enrichment and Structure Indices according to Ferris et al. (2001). Nematode indices that measure the response of the nematode community to environmental stress, such as the Maturity Index and the Plant Parasitic Index, were also calculated (Bongers, 1990).

Nematode metabolic footprints include weightings of each group's size-dependent metabolic activity, estimating the contribution of nematodes to various ecosystem functions (Ferris, 2010). Building on the nematode indices, which take into account $\mathrm{Cp}$ group and abundance, nematode metabolic footprints use estimates of body size from published morphometric parameters and assumptions about carbon utilised in biomass production and respiration (Ferris, 2010; Ferris et al., 2012). Calculated footprints included the nematode Bacterial and Fungal Metabolic Footprints, as well as the Structure and Enrichment Footprints. Calculations of indices and metabolic footprints were completed using the R, shiny package, NINJA: 'Nematode INdicator Joint Analysis' (Sieriebriennikov et al., 2014). Nematodes in the family Tylenchidae have been classified mostly as epidermal root hair feeders (Yeates et al., 1993) but some genera also feed on fungi (Okada et al., 2002, 2005; Okada \& Kadota, 2003). Therefore, in calculating nematode indices, the abundance of Tylenchidae was split, with half categorised as plant parasites (Cp-2) and half as fungal feeders (Cp-2), reflecting the uncertainty of feeding preferences in this group.

\section{SOIL ANALYSIS}

Soils were analysed for soil properties which could potentially affect nematode distribution such as sand, silt and clay fractions (particle size), labile soil organic matter and soil nitrogen $(\mathrm{N})$ and carbon $(\mathrm{C})$ content (Hodson et al., 2014; Margenot \& Hodson, 2016). For mineral soil properties, which were not expected to change from year to year, samples were analysed from year 3 of sampling only (2016). Soil was dried at $60^{\circ} \mathrm{C}$, and sieved to $2 \mathrm{~mm}$. Soil particle sizes were determined by laser diffraction on a Beckman-Coulter LS-230 Particle Size Analyzer (Eshel et al., 2004). Finely ground soil was analysed for total N (\%) and C (\%) on a Europe Hydra 20/20 isotope ratio mass spectrometer at the University of California Davis Stable Isotope Facility. Labile soil carbon (POXC) was measured in both years 2 and 3 of sampling (2015 and 2016). A subsample of ground soil from all plots and sites was analysed for POXC following Culman et al. (2012). Briefly, triplicate samples of $2.5 \mathrm{~g}$ soil were oxidised with $0.02 \mathrm{~mol} \mathrm{l}^{-1} \mathrm{KMnO}_{4}$ with 2 min shaking followed by 10 min incubation and non-reduced $\mathrm{Mn}^{7+}$ quantified by colorimetry.

\section{STATISTICAL ANALYSIS}

All analyses of nematode communities and ecological indices were performed in R v.3.1.1 (R Core Team, 2014). For biological data, we used the package lme4 (Bates $e t$ al., 2015) to perform a linear mixed effects analysis of the relationship between each sampled block, treatment, time and nematode indices. As fixed effects, we entered Treatment. As random effects, we had intercepts for year, sample location, blocks and orchard row. Assumptions of normality and homoscedasticity were assessed by visual inspection of residual plots and nematode indices were occasionally $\log$ transformed in models to meet these assumptions (graphs report non-transformed values). $P$ values were obtained using the package lmerTest (Kuznetsova et al., 2017) and posthoc Tukey comparisons were done with the package multcomp (Hothorn et al., 2008) applying the false discovery rate adjustment. Similar models were run with year as a fixed effect, to test for increases in nematode abundances over time. Differences in indices and the relative abundance of nematode groups within individual years were compared by Kruskal-Wallis tests (denoted by the coefficient Chi), since with the lower sample sizes in individual years, data violated assumptions of normality. Kruskal-Wallis tests were also used to test for differences in soil variables between the sites and between treatments within an individual site. Since nematode data were non-normally distributed, often including zeros or outliers, medians are reported in the tables and 
figures, along with either the minimum and maximum values or the interquartile range.

For year 3 measurements, non-metric multidimensional scaling (NMDS) was conducted to determine the degree to which site factors and treatments still influenced nematode community composition. A Chao distance measure for the abundance of nematode groups was run using the metaMDS function in the vegan package (Oksanen $e t$ al., 2018). Abundance data was Wisconsin double standardised and square root transformed. Correlations between the NMDS ordinations of nematode communities and treatment were tested with loop permutations (999) in the envfit function. The final stress value of the reported analysis, which measures the level of disagreement between the 2-D configuration and predicted values from the regression, was 0.06 for Site Merced and 0.09 for Stanislaus. To examine the relationship between nematode abundance and environmental data, two-tailed Spearman rank correlations were performed.

\section{Results}

\section{SOIL PROPERTIES}

Although both classified as sandy loam soil, the two sites differed slightly in specific soil characteristics (Table 1). The Stanislaus site had less sand compared to Merced $(\mathrm{Chi}=10.6, P<0.01)$, particularly coarse sand $(\mathrm{Chi}=4.2, P=0.04)$ and was higher in \% $\mathrm{C}(\mathrm{Chi}=$ $14.3, P<0.01), \% \mathrm{~N}(\mathrm{Chi}=14.3, P<0.01)$ and $\mathrm{C}: \mathrm{N}$ (Chi $=5.5, P=0.02)$. For the two time points in which the labile soil $\mathrm{C}$ fraction, POXC, was measured, levels increased between year 2 and year 3 at Merced (Chi $=9.1$, $P<0.01$ ), while levels remained similar at Stanislaus. In both years $2(\mathrm{Chi}=13.7, P<0.01)$ and $3(\mathrm{Chi}=9.6$, $P<0.01)$, POXC was 75 and $48 \%$ higher at Stanislaus compared to Merced, respectively (Table 1).

\section{NEMATODE COMMUNITIES}

A total of 22 nematode taxa were identified in the two almond orchards (Table 2). The most abundant groups across locations and treatments were bacterial feeders such as Rhabditis (with relative abundances as high as $38 \%$ ), Acrobeloides (up to $61 \%$ ), as well as the fungalfeeding Aphelenchoides (up to 68\%). Nematodes in the family Tylenchidae, which can be either fungal feeders or root hair feeders, were also very common, accounting for up to $20 \%$ of all nematodes at Merced in year 2. While the overall community composition of the two sites was
Table 1. Average soil properties at $0-46 \mathrm{~cm}$ depth of the soil profile at two almond orchards, one in Merced County and the other in Stanislaus County, CA, USA.

\begin{tabular}{lcc}
\hline $\begin{array}{l}\text { Soil properties } \\
(0-46 \mathrm{~cm} \text { depth) }\end{array}$ & Merced County & Stanislaus County \\
\hline $\mathrm{C}(\%)$ & $0.34 \pm 0.03$ & $0.92 \pm 0.66^{*}$ \\
$\mathrm{~N}(\%)$ & $0.04 \pm 0.003$ & $0.10 \pm 0.006^{*}$ \\
$\mathrm{C}: \mathrm{N}$ & $8.14 \pm 0.29$ & $8.85 \pm 0.14^{*}$ \\
Clay (\%) & $0.99 \pm 0.08$ & $0.77 \pm 0.07$ \\
Silt $(\%)$ & $28.74 \pm 1.31$ & $37.80 \pm 1.56^{*}$ \\
Sand $(\%)$ & $70.27 \pm 1.35$ & $61.42 \pm 1.59^{*}$ \\
Very fine sand (\%) & $13.02 \pm 0.87$ & $13.58 \pm 0.47$ \\
Fine sand (\%) & $12.02 \pm 0.79$ & $11.02 \pm 0.29$ \\
Medium sand (\%) & $20.02 \pm 0.75$ & $18.35 \pm 0.68$ \\
Coarse sand (\%) & $18.32 \pm 1.72$ & $13.48 \pm 1.48^{*}$ \\
POXC 2015 (mg & $147.51 \pm 24.86$ & $597.67 \pm 30.50^{*}$ \\
$\left.\quad(\mathrm{~kg} \text { soil) })^{-1}\right)$ & & \\
POXC 2016 (mg & $280.91 \pm 18.73$ & $536.86 \pm 37.95^{*}$ \\
$\quad(\mathrm{~kg}$ soil) & & \\
Soil texture class & Sandy loam & Sandy loam \\
\hline
\end{tabular}

Values are means \pm standard error. For particle size classifications, clay $(0.041-2.0 \mu \mathrm{m})$, silt $(2-47.94 \mu \mathrm{m})$, sand (47.94-2000 $\mu \mathrm{m})$, very fine sand $(62.5-125 \mu \mathrm{m})$, fine sand $(125-250 \mu \mathrm{m})$, medium sand $(250-500 \mu \mathrm{m})$, and coarse sand $(500-1000 \mu \mathrm{m})$. Asterisks denote statistical differences at the $P<0.05$ level by Kruskal-Wallis tests.

similar, Stanislaus had higher median abundance of pest nematodes such as Paratylenchus $(\mathrm{Chi}=12.1, P<0.01)$ and Tylenchorhynchus $(\mathrm{Chi}=13.9, P<0.01)$ in year 3 (Supplementary Table S1).

At Merced, fumigation decreased values of indices that measure ecological structure and maturity, although these effects were variable between years (Table 3). In year 1, fumigated plots had ten times lower levels of the Structure Index than controls (Chi $=4.5, P=$ 0.03). Although levels of the Structure Index dropped to zero in year 2 for both treatments, by year 3 fumigated plots again had Structure Indices five times lower than controls $(\mathrm{Chi}=3.9, P=0.04)$, largely driven by reductions in the relative abundance of large predatory Mononchidae (Supplementary Table S1, Chi $=4.5, P=$ 0.03 ). While only one of the five fumigated samples had Mononchidae, they were present in abundances of greater

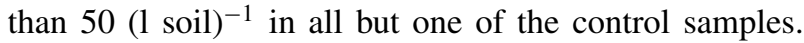
There were no statistically significant differences in the Maturity Index between treatments (Fig. 1A). However, the Maturity Index 2-5, which excludes opportunistic bacterial feeders and thus places more emphasis on higher trophic levels, was lower with fumigation in years 1 
Table 2. Nematode taxa identified from soil samples $(0-46 \mathrm{~cm}$ depth) taken from almond orchards in Merced and Stanislaus Counties, CA, USA, during 2014-2016.

\begin{tabular}{|c|c|c|c|}
\hline Bacterivores & Fungivores & Herbivores & Predators/Omnivores \\
\hline Panagrolaimus & Aphelenchoides & Meloidogyne & Qudsianematidae \\
\hline Rhabditis & Aphelenchus & Trichodorus & Mesodorylaimus \\
\hline Cephalobus & & Tylenchidae & Microdorylaimus \\
\hline Eucephalobus & & Paratylencchus & Discolaimus \\
\hline Acrobeles & & Tylenchorhynchus & Mononchidae \\
\hline Acrobeloides & & Pratylenchus & \\
\hline \multirow[t]{2}{*}{ Prismatolaimus } & & Xiphinema & \\
\hline & & Mesocriconema & \\
\hline
\end{tabular}

Table 3. Median nematode indices for soil samples $(0-46 \mathrm{~cm}$ depth) taken from almond orchards in Merced County, CA, USA and Stanislaus County, CA, USA.

\begin{tabular}{|c|c|c|c|c|c|c|}
\hline \multirow[t]{2}{*}{ Nematode index } & \multicolumn{2}{|c|}{2014} & \multicolumn{2}{|c|}{2015} & \multicolumn{2}{|c|}{2016} \\
\hline & $\mathrm{C}$ & $\mathrm{F}$ & $\mathrm{C}$ & $\mathrm{F}$ & $\mathrm{C}$ & $\mathrm{F}$ \\
\hline \multicolumn{7}{|l|}{ Merced County, CA, USA } \\
\hline Maturity Index & 1.9 & 1.7 & 2.0 & 1.9 & 2.0 & 1.9 \\
\hline Min-Max & $1.7-2.0$ & $1.6-2.0$ & $1.5-2.1$ & $1.7-2.0$ & $2.0-2.3$ & $1.7-2.2$ \\
\hline Maturity Index 2-5 & 2.1 & $1.7^{*}$ & 2.0 & 2.0 & 2.3 & $2.0^{*}$ \\
\hline Min-Max & $2.0-2.1$ & $1.6-2.0$ & $2.0-2.2$ & $2.0-2.0$ & $2.2-2.4$ & $2.0-2.3$ \\
\hline Plant Parasitic Index & 2.2 & 2.2 & 2.7 & 2.1 & 2.2 & $2.0^{*}$ \\
\hline Min-Max & $2.0-2.6$ & $2.0-2.5$ & $2.4-3.5$ & $2.0-2.7$ & $2.1-2.3$ & $2.0-2.2$ \\
\hline Channel Index & 56.5 & 30.4 & 27.3 & 24.5 & 31.0 & 24.0 \\
\hline Min-Max & $29.6-74.7$ & $20-91.2$ & $7.3-100$ & $2.1-100$ & $19.5-56.4$ & $9.5-81.4$ \\
\hline Enrichment Index & 55.0 & 74.8 & 38.5 & 30.6 & 58.2 & 50.0 \\
\hline Min-Max & $50.4-72.8$ & $51.6-79.3$ & $22.1-82.8$ & $27.6-62.4$ & $36.7-65.7$ & $44.1-71.8$ \\
\hline Structure Index & 11.7 & $0.0^{*}$ & 0.0 & 0.0 & 43.4 & $8.4^{*}$ \\
\hline Min-Max & $0-13.6$ & $0-2.3$ & $0-31.1$ & $0-2.4$ & $38.4-57.4$ & $2.8-44.3$ \\
\hline Enrichment Met. Ft. & 178.1 & 284.3 & 122.6 & 78.6 & 357.6 & 640.5 \\
\hline Min-Max & $79-449$ & $152-929$ & $9-1837$ & $61.4-2168$ & & \\
\hline Structure Met. Ft. & 60.2 & 0.0 & 0.0 & 0.0 & 176.1 & 15.6 \\
\hline Min-Max & $0-139$ & $0-47.8$ & $0-95$ & $0-6.2$ & $51.9-405$ & $3.7-265.4$ \\
\hline Herbivore Met. Ft. & 6.6 & $0.9^{*}$ & 363.3 & 3.9 & 29.8 & 21.9 \\
\hline Min-Max & $1.6-8.4$ & $0-4.2$ & $181-1202$ & $0-2296$ & $5.1-62.1$ & $6.9-111.3$ \\
\hline Fungal Met. Ft. & 36.4 & 27.4 & 9.2 & 15.4 & 49.0 & 21.6 \\
\hline Min-Max & $14.5-51.8$ & $18.2-93.7$ & $2.7-71.9$ & $12.7-25.5$ & $19.4-68.2$ & $19.4-276$ \\
\hline Bacterial Met. Ft. & 149.1 & 268.7 & 174.2 & 137.4 & 487.4 & 1135.0 \\
\hline Min-Max & $78.6-433$ & $60.8-906$ & $41.8-1855$ & $65.8-3355$ & $363-823$ & $94.3-2146$ \\
\hline Predator Met. Ft. & 0.0 & 0.0 & 0.0 & 0.0 & 133.3 & 0.0 \\
\hline Min-Max & $0-8.6$ & $0-0$ & $0-44.9$ & $0-0$ & $0-321.8$ & $0-161.6$ \\
\hline Omnivore Met. Ft. & 51.6 & 0.0 & 0.0 & 0.0 & 0.0 & 0.0 \\
\hline Min-Max & $0-138.8$ & $0-47.8$ & $0-21.4$ & $0-0$ & $0-0$ & $0-0$ \\
\hline Total nematodes $(1 \text { soil })^{-1}$ & 803.9 & 643.4 & 1105.0 & 1790.0 & 2260.0 & 2440.0 \\
\hline Min-Max & $413-1017$ & $390-1296$ & $585-3140$ & $1405-6030$ & $2180-3540$ & $1020-8480$ \\
\hline$\%$ Herbivores & 8.0 & $1.6^{* *}$ & 20.0 & 1.4 & 13.5 & 8.9 \\
\hline Min-Max & $5.5-13.3$ & $0-5.4$ & $13.3-33.8$ & $0-39.5$ & $3.2-44$ & $3.8-29$ \\
\hline$\%$ Fungal-feeding & 57.8 & 60.0 & 13.6 & 8.7 & 19.9 & 24.5 \\
\hline Min-Max & $46.3-72.4$ & $41.1-93.3$ & $6.7-28.6$ & $2.5-27$ & $14.1-35.9$ & $11.5-38$ \\
\hline$\%$ Bacterial-feeding & 29.7 & 40.0 & 68.2 & 90.7 & 58.3 & 55.3 \\
\hline Min-Max & $13.2-48.1$ & $5.1-53.6$ & $46.9-80$ & $39.7-97.5$ & $29.3-72$ & $36-84.6$ \\
\hline
\end{tabular}


Table 3. (Continued.)

\begin{tabular}{|c|c|c|c|c|c|c|}
\hline \multirow[t]{2}{*}{ Nematode index } & \multicolumn{2}{|c|}{2014} & \multicolumn{2}{|c|}{2015} & \multicolumn{2}{|c|}{2016} \\
\hline & $\mathrm{C}$ & $\mathrm{F}$ & $\mathrm{C}$ & $\mathrm{F}$ & $\mathrm{C}$ & $\mathrm{F}$ \\
\hline \multicolumn{7}{|l|}{ Stanislaus County, CA, USA } \\
\hline Maturity Index & 1.9 & 1.9 & 2.0 & 1.8 & 2.1 & 2.1 \\
\hline Min-Max & $1.9-2.0$ & $1.4-2.0$ & $1.9-2.1$ & $1.7-2.0$ & $2.0-2.2$ & $2.0-2.5$ \\
\hline Maturity Index 2-5 & 2.0 & 2.0 & 2.1 & 2.0 & 2.3 & 2.5 \\
\hline Min-Max & $2.0-2.0$ & $2.0-2.0$ & $2.0-2.3$ & $2.0-2.0$ & $2.2-2.4$ & $2.2-2.6$ \\
\hline Maturity Index 2-5 & 2.7 & 2.0 & 2.1 & 2.2 & 2.4 & 2.5 \\
\hline Min-Max & $2.0-3.0$ & $2.0-2.0$ & $2.0-2.8$ & $2.0-2.7$ & $2.0-2.9$ & $2.1-2.6$ \\
\hline Channel Index & 72.1 & 47.0 & 43.2 & 13.7 & 15.2 & 30.2 \\
\hline Min-Max & $68.5-100$ & $4.3-100$ & $15.6-100$ & $1.9-18.1$ & $5.9-52.8$ & $6.9-85.4$ \\
\hline Enrichment Index & 50.0 & 52.8 & 38.7 & 50.2 & 56.9 & 57.5 \\
\hline Min-Max & $43.7-53.1$ & $47.6-87.3$ & $15.6-59.9$ & $19.1-59.3$ & $54.6-71.9$ & $48.1-79.0$ \\
\hline Structure Index & 0.0 & 0.0 & 10.7 & 1.6 & 48.6 & 57.7 \\
\hline Min-Max & $0-0$ & $0-0$ & $1.6-45.8$ & $0-8.8$ & $33.4-58.9$ & $35.8-62.6$ \\
\hline Enrichment Met. Ft. & 418.7 & 228.5 & 81.9 & 420.7 & 1723.5 & 640.8 \\
\hline Min-Max & $183-1643$ & $61-2372$ & $27.8-1788$ & 59.6-1155 & $1000-2417$ & $578-2866$ \\
\hline Structure Met. Ft. & 0.0 & 0.0 & 59.7 & 1.4 & 334.0 & 441.2 \\
\hline Min-Max & $0-0$ & $0-0$ & $2.2-570.3$ & $0-120.9$ & $185-563$ & $153-1098$ \\
\hline Herbivore Met. Ft. & 9.1 & $0.6^{*}$ & 14.9 & 7.1 & 346.0 & 142.9 \\
\hline Min-Max & $4.1-82$ & $0-4.9$ & $6.2-28.4$ & $2.5-14.1$ & $66.6-387.9$ & $104-836$ \\
\hline Fungal Met. Ft. & 145.2 & $19.2^{* *}$ & 28.2 & 14.2 & 68.6 & 100.1 \\
\hline Min-Max & $127-482$ & $13-104$ & $8.6-67.2$ & $2.2-31.6$ & $23.7-357.4$ & $28.9-432.8$ \\
\hline Bacterial Met. Ft. & 347.9 & 226.2 & 169.1 & 514.2 & 2092.0 & 891.7 \\
\hline Min-Max & $48-1335$ & $13-2395$ & $60.4-2064$ & $353-1322$ & $1071-2946$ & $451-081$ \\
\hline Predator Met. Ft. & 0.0 & 0.0 & 0.0 & 0.0 & 0.0 & 0.0 \\
\hline Min-Max & $0-0$ & $0-0$ & $0-200$ & $0-14.6$ & $0-33$ & $0-46.2$ \\
\hline Omnivore Met. Ft. & 0.0 & 0.0 & 58.2 & 0.0 & 121.4 & 359.5 \\
\hline Min-Max & $0-0$ & $0-0$ & $0-317.8$ & $0-87.6$ & $0-314.4$ & $29-1064$ \\
\hline${\text { Total nematodes }(1 \text { soil })^{-1}}^{-1}$ & 2955.0 & 995.0 & 1945.0 & 2680.0 & 10524.0 & 6340.0 \\
\hline Min-Max & $2225-9765$ & $380-1905$ & $610-4990$ & $1450-3940$ & 8420-15 534 & $5260-13008$ \\
\hline$\%$ Herbivores & 3.6 & 1.3 & 12.3 & 4.6 & 38.2 & 24.4 \\
\hline Min-Max & $1.0-6.8$ & $0-11.1$ & $7.5-15.6$ & $1.2-12.5$ & $20.1-48.4$ & $13.7-56.2$ \\
\hline$\%$ Fungal-feeding & 64.7 & 45.8 & 17.0 & 6.5 & 7.4 & 21.6 \\
\hline Min-Max & $55.2-79.6$ & $11.1-90.7$ & $13.4-21.7$ & $2.0-10.8$ & 3.6-39.2 & $4.9-43.8$ \\
\hline$\%$ Bacterial-feeding & 30.4 & 50.6 & 67.4 & 89.0 & 47.5 & 32.1 \\
\hline Min-Max & $18.3-41.2$ & $9.3-89.0$ & $61.8-75.5$ & $76.7-95.9$ & $35.6-53.9$ & $15-58.8$ \\
\hline
\end{tabular}

Statistical differences from Kruskal-Wallis rank sum tests are denoted by $*$ for $P<0.05$ and $* *$ for $P<0.01$. C $=$ control, $\mathrm{F}=$ fumigated. Nematode metabolic footprints (Met. Ft.) are expressed as $\mu \mathrm{g} \mathrm{C}(1 \mathrm{soil})^{-1}$.

$($ Chi $=4.5, P=0.03)$ and $3(\mathrm{Chi}=4.8, P=0.03)$, but not in year 2 (Table 3 ).

At Merced, fumigation treatments decreased plantparasitic nematodes in the first year but did not alter ratios of bacterial and fungal feeders (Table 3 ). In year 1, fumigation reduced the relative abundance of plant-parasitic and root-herbivore nematodes $(\mathrm{Chi}=6.8, P<0.01)$, and also reduced the Herbivore Metabolic Footprint $(\mathrm{Chi}=$ 4.8, $P=0.03$ ), due to lower numbers of Tylenchidae (Supplementary Table S1, Chi $=5.7, P=0.02$ ). By year 3, fumigated trees had lower numbers of Paratylenchus (Chi $=3.5, P=0.05$ ) and also Pratylenchus (Chi $=5.1, P=0.02)$, which contributed to slightly lower Plant Parasitic Indices compared to controls (Table 3 , Chi $=5.1, P=0.02$ ). In mixed models, the relative abundance of bacterial feeders (Fig. $2 \mathrm{~A}, F=7.6$, $P=0.01)$ as well as the Bacterial Metabolic Footprint (Table $3, F=6.7, P=0.02$ ) increased over time although there were no significant effects due to treatment. 



Fig. 1. The nematode Maturity Index calculated from soil samples $(0-46 \mathrm{~cm}$ depth) taken from almond orchards in A: Merced County; B: Stanislaus County, CA, USA. Bars are medians, boxes the upper and lower quartiles (25 and $75 \%$ ), lines are the minimum and maximum values and outliers are dots.
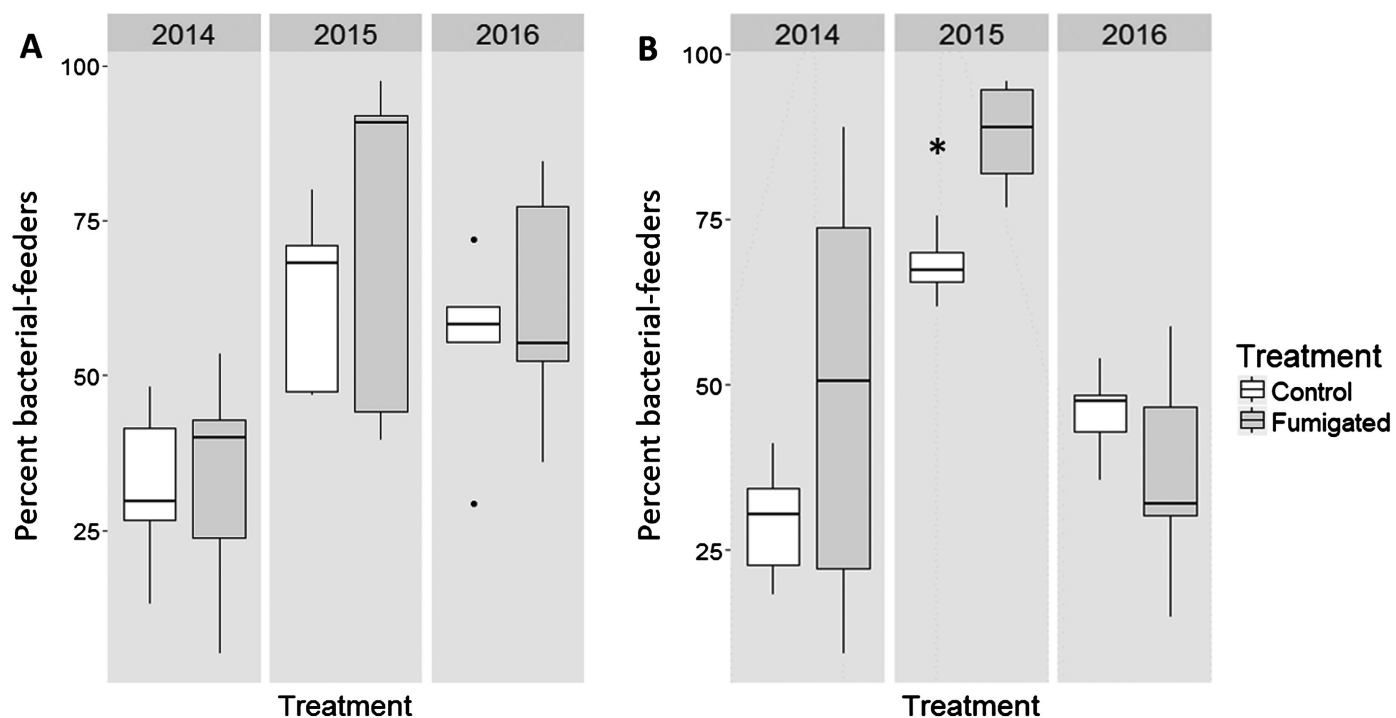

Fig. 2. The relative abundance (percent of total) of the nematode community comprised by bacterial feeders. Soil samples $(0-46 \mathrm{~cm}$ depth) were taken from almond orchards in A: Merced County; B: Stanislaus County, CA, USA. Statistical differences from Kruskal Wallis rank sum tests at the $P<0.05$ level are denoted by asterisk $(*)$. Bars are medians, boxes the upper and lower quartiles $(25$ and $75 \%$ ), lines are the minimum and maximum values and outliers are dots.

By contrast, fungal feeders decreased in relative abundance over time (Fig. 3A, $F=9.2, P<0.01$ ).

In the Stanislaus orchard, the response of the nematode community to fumigation was less than Merced, and varied between years. One consistent trend was that for both treatments the Maturity Index increased over time during the 3 years measured (Fig. 1B, Chi $=13.9, P<$ 0.01). However, there were no statistically significant differences in the Maturity Index between treatments within individual years.

Fumigation decreased the Herbivore Metabolic Footprint and groups of plant-parasitic nematodes at Stanislaus in certain years. In year 1, the Herbivore Metabolic Footprint was 15 times higher in control plots compared to fumigated plots (Table 3, Chi $=4.8, P=0.03$ ). There were no statistically significant differences in plant parasites in year 2. Abundances of Paratylenchus, Tylenchorhynchus and Pratylenchus had increased by year 3, and these genera also had higher relative abundance in controls than fumigated treatments (Supplementary Table S1; Chi $=3.8$, $P=0.05)$.

The Bacterial Metabolic Footprint increased over time at the Stanislaus site and bacterial-feeders responded positively to fumigation at certain time points. Similar to 

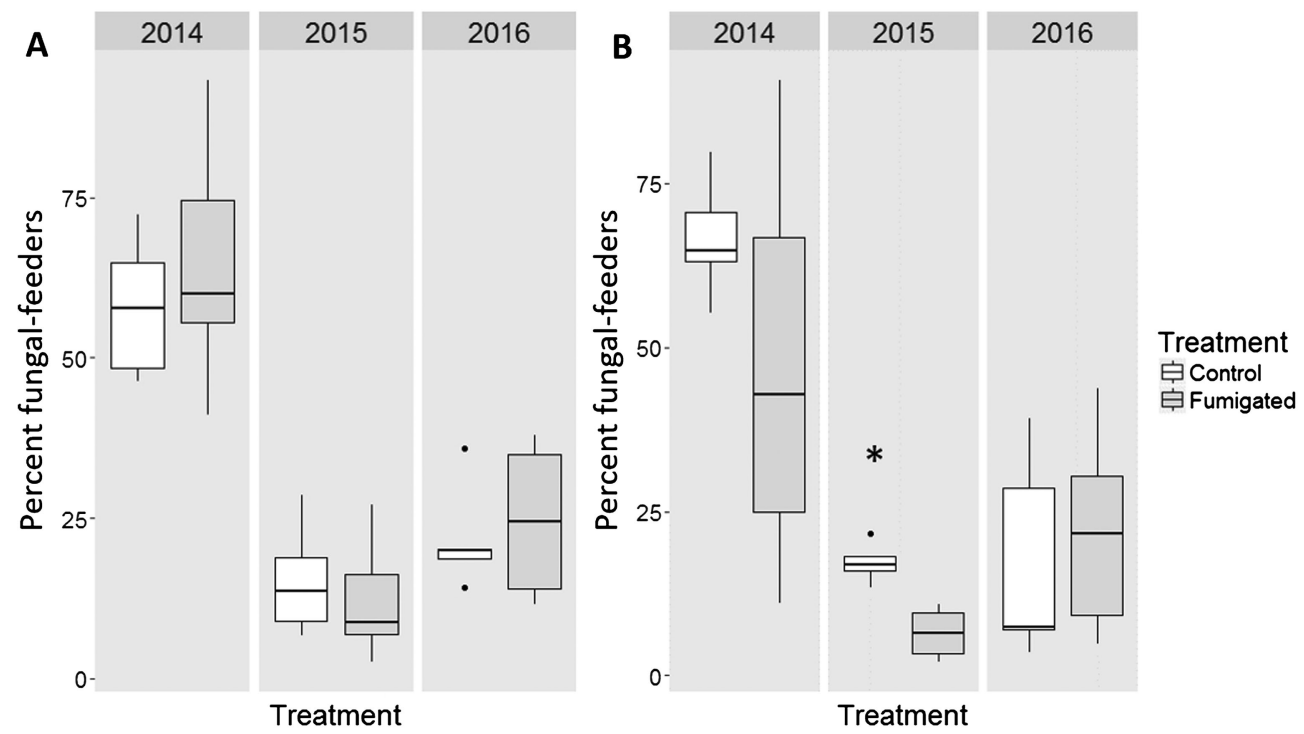

Fig. 3. The relative abundance (percent of total) of the nematode community comprised by fungal feeders. Soil samples (0-46 cm depth) were taken from almond orchards in A: Merced County; B: Stanislaus County, CA, USA. Statistical differences from Kruskal Wallis rank sum tests at the $P<0.05$ level are denoted by an asterisk $\left(^{*}\right)$. Bars are medians, boxes the upper and lower quartiles $(25$ and $75 \%)$, lines are the minimum and maximum values and outliers are dots.

Merced, the Bacterial Metabolic Footprint increased over time for both treatments $(Z=10.0, P<0.01)$ in mixed effects models. Bacterial feeders made up a higher proportion of the nematode community under fumigated trees than controls in year 2 (Table 3 , Chi $=5.3, P=0.02$ ) and included groups such as Panagrolaimus, Rhabditis, Cephalobus, Eucephalobus, Acrobeles and Acrobeloides. The most abundant genus was Acrobeloides, with a median relative abundance of $61.0 \%$ in fumigated plots compared to $44.4 \%$ in controls (Supplementary Table S1, Chi $=5.3, P=0.02$ ).

In contrast to bacterial-feeding nematodes, fungalfeeding nematodes decreased over time in the Stanislaus orchard and responded negatively to fumigation (Fig. 3, $Z=15.5, P<0.01)$. In year 1 , soon after the orchard had been established and fumigated, fungalfeeding nematodes were still quite numerous, making up $64.7 \%$ of all nematodes in control treatments and $45.8 \%$ in fumigated treatments. Fungal Metabolic Footprints, with a median $19.2 \mu \mathrm{g} \mathrm{C}$ sample ${ }^{-1}$ in fumigated treatments, were 6.5 times lower than controls, which had a median Fungal Metabolic Footprint of $145.2 \mu \mathrm{g} \mathrm{C}$ sample $^{-1}$ (Table 3, Chi $=6.8, P<0.01$ ). In year 2 , the relative abundance of fungal feeders was still higher in control plots than fumigated plots $(\mathrm{Chi}=5.3, P=0.02)$. By year 3 there were no statistical differences in fumigation between the treatments.

\section{RELATIONSHIP BETWEEN NEMATODE COMMUNITIES, SOIL PROPERTIES AND FUMIGATION}

By the third year of the experiment at Merced, nematode communities were still influenced by fumigation according to NMDS analysis $\left(P=0.01, R^{2}=0.51\right)$, mainly through differences in herbivorous and predatory nematode groups (Fig. 4). For example, control treatments were associated with predatory nematodes in the family Mononchidae and the relative abundances of the plant-parasitic nematodes Paratylenchus and Pratylenchus. Correlations showed that the abundances of certain bacterial feeders varied with soil physical and chemical factors. For example, the abundance of Acrobeles increased with the percent medium sand $(\mathrm{Rho}=0.68$, $P=0.03)$. Rhabditis increased with soil C $(\mathrm{Rho}=0.62$, $P=0.05)$ and soil $\mathrm{N}($ Rho $=0.66, P=0.04)$, while Prismatolaimus decreased with these factors $($ Rho $=$ $-0.67, P=0.03$, Rho $=-0.70, P=0.03$, respectively).

At Stanislaus in year 3, nematode communities were also influenced by fumigation according to NMDS analysis (Fig. $5, R^{2}=0.35, P=0.01$ ). In the ordination, plant-parasitic nematodes, such as Pratylenchus and Tylenchorhynchus, were associated more with control treatments, as were certain bacterial feeders such as Cephalobus and Prismatolaimus. In correlations, sev- 


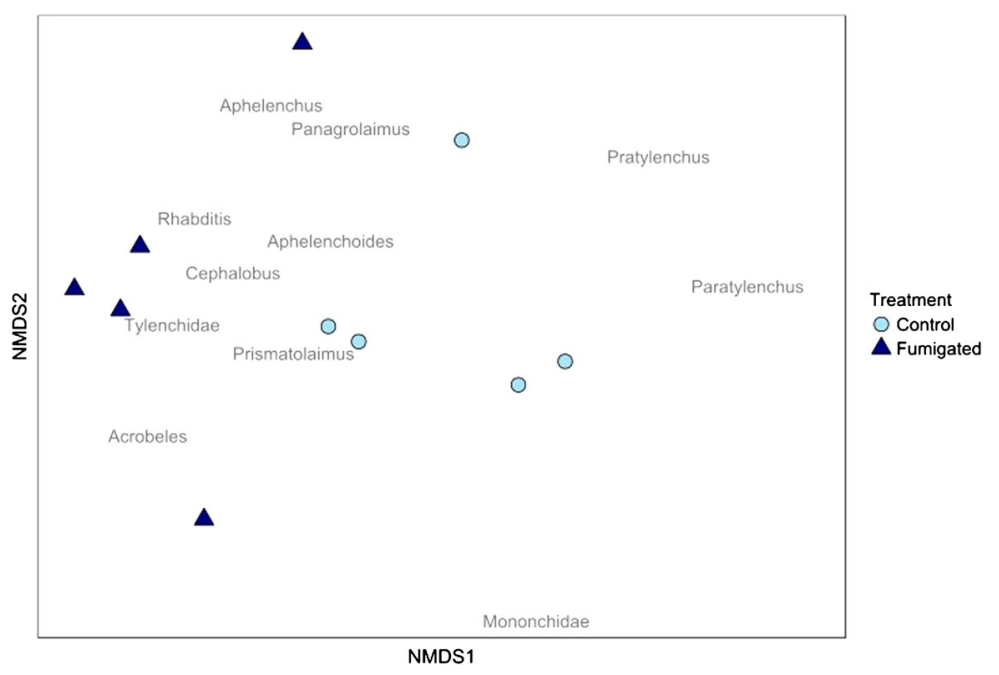

Fig. 4. Nonmetric multidimensional scaling analyses of soil nematode communities from soil samples $(0-46 \mathrm{~cm}$ depth) taken from an almond orchard in Merced County, CA, USA, and their relationship to fumigation treatment in 2016.

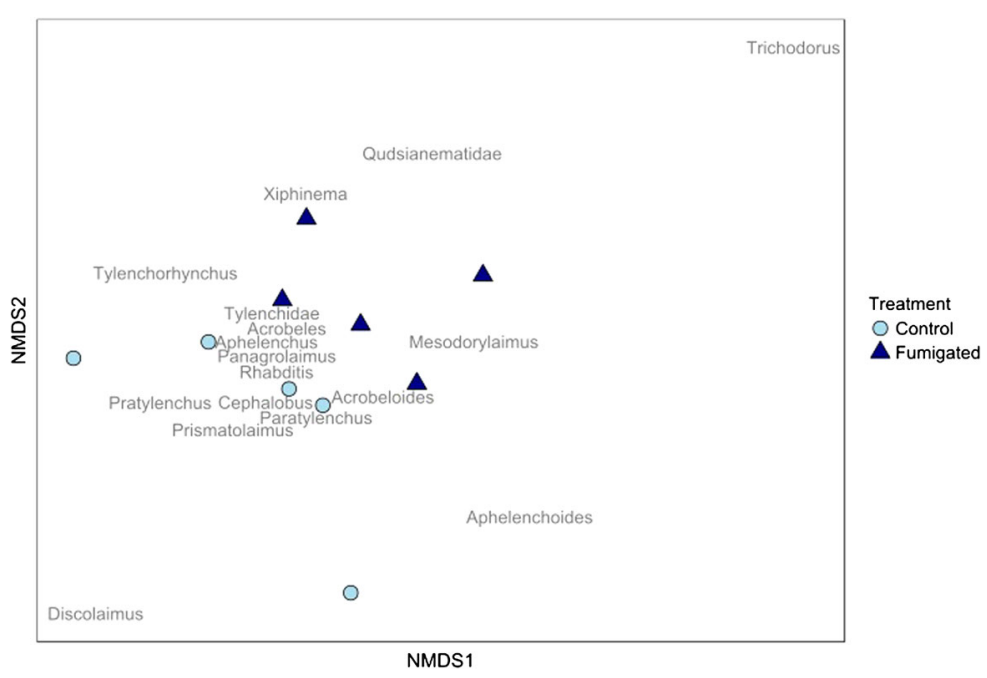

Fig. 5. Nonmetric multidimensional scaling analysis of soil nematode communities from soil samples $(0-46 \mathrm{~cm}$ depth) taken from an almond orchard in Stanislaus County, CA, USA, and their relationship to fumigation treatment in 2016.

eral nematode groups showed relationships with environmental site variables. Larger-bodied Mesodorylaimus increased with the percent sand (Rho $=0.77, P<0.01)$. When sand was broken down into smaller size fractions, Acrobeloides (Rho $=0.68, P=0.03$ ) increased with the percentage fine sand and Rhabditis (Rho $=0.71, P=$ $0.02)$ with the percentage very fine sand $(62.5-125 \mu \mathrm{m})$. Rhabditis also increased with the $\mathrm{C}: \mathrm{N}$ ratio of the soil (Rho $=0.72, P=0.02$ ). Nematodes in the family Tylenchidae, which have unclear feeding preferences, were associated with increased $\mathrm{C}$ (Rho $=0.76, P=0.01)$,
$\mathrm{N}$ (Rho $=0.65, P=0.04)$ and the carbon pool POXC (Rho $=0.83, P<0.01)$.

\section{Discussion}

The goals of this study were to quantify changes in nematode community structure associated with fumigation. Nematodes serve as useful biological indicators of changes in the soil environment (Ritz et al., 2009) since they represent all trophic levels, co-vary with the abun- 
dance of other soil biota such as mites (Sánchez-Moreno et al., 2009) and respond rapidly to changes in management (Kapp et al., 2013). This study suggests that treatment with 1,3-D and chloropicrin influences nematodes communities up to 2 years after fumigation, decreasing the abundance of fungal-feeding and predatory nematodes, but occasionally increasing bacterial-feeding nematodes compared to non-treated controls.

Regardless of treatment, metrics of nematode community structure increased between years 1 and 3 after fumigation, probably as nematodes recovered from the physical disturbance of orchard establishment and the planted trees began to grow. Preparing for orchard planting is a disruptive process that involves deep tilling and shaping the raised berms where almonds are planted (Flint, 2002). In other cropping systems, similar tillage practices caused reductions in predatory nematodes and increases in bacterial feeders, decreasing levels of the Maturity Index (Lenz \& Eisenbeis, 2000; Sánchez-Moreno et al., 2006). However, it has also been found that tillage has a minimal influence on nematode communities (Griffiths et al., 2009). In the current study, some indices of ecological complexity slowly increased after orchard establishment in both fumigated and control plots, such as the Maturity Index.

Fumigation disproportionately affected certain nematode taxa, particularly higher trophic level omnivores and predators; however, the two sites differed in the degree to which this was so. The effects of fumigation were immediately apparent at Merced, with lower levels of the Structure Index, an indicator of food web complexity, in fumigated plots, but other metrics, such as the Maturity Index, were unaffected. By contrast, no large changes were seen at Stanislaus in the Structure Index or the Maturity Index. Wall et al. (2002) noted that the Maturity Index provided contradictory results to other diversity indices and failed to separate sites that showed differences in multivariate analysis. In other studies after fumigation, values of the Maturity Index gradually increased, with differential rates of recovery of nematode species (Ettema \& Bongers, 1993). At both sites in the current study, the relative abundance of Prismatolaimus was low in years 1 and 2, but increased more in control plots than fumigated plots by year 3 . These nematodes, typically classified as generalist bacterial feeders (Yeates et al., 1993), are more sensitive to disturbance, as indicated by their c-p value of 3 (Bongers, 1990), and have been classified by some as omnivores (Ferris et al., 1996). Since these nematodes are relatively common in mature orchards, and were less numerous in fumigated plots at Stanislaus, their abundance could serve as a useful indicator of fumigant effects on nematode communities.

The rate of recovery of predatory and omnivore nematodes may depend on site-dependent field characteristics (Sánchez-Moreno et al., 2010; Timper et al., 2012). In this study, strong effects on the Structure Index were seen at Merced but not Stanislaus. Stanislaus had a lower sand content, at $60 \%$, compared to $70 \%$ at Merced. Collins et al. (2006) found that bacteria and fungi were more likely to survive fumigation with metam sodium and 1,3-D in fine-compared to coarse-textured soil, perhaps due to reduced diffusion of the fumigant through soil pore spaces. Compared to Merced, Stanislaus also had nearly three times more soil $\mathrm{C}$ and twice the POXC, a labile carbon pool correlated with particulate organic carbon, microbial biomass carbon and soil organic carbon (Culman et al., 2012). As soil organic matter content increases, more volatiles adhere to the surface of the organic matter, reducing available fumigant (Lembright, 1990). The microbial activity promoted by organic amendments can also degrade fumigants (Gan et al., 1998), reducing their effects on microbial communities (Dungan et al., 2003) and therefore their effectiveness. It could be that the history of prior orchard management at Stanislaus contributed to higher soil $\mathrm{C}$, since peach trees are pruned heavily each year and the wood is shredded in place on the orchard.

Nematode communities at both sites were still influenced by fumigation in year 3 according to NMDS ordinations. This was partly due to the effects of plant parasites, such as Pratylenchus, which were associated with controls at both sites. While predators such as Mononchidae were negatively associated with fumigation at Merced, omnivorous nematodes such as Mesodorylaimus and Qudsianematidae were not dramatically affected by fumigation at Stanislaus, perhaps reflecting their tolerances to disturbance or feeding preferences. Nematodes such as bacterial-feeding Rhabditis were correlated with higher soil $\mathrm{C}$ and $\mathrm{N}$, possibly relating to increased food resources for these nematodes (Ferris \& Bongers, 2006). Similar to other studies in the same region, largerbodied Mesodorylaimus increased with the percentage sand, probably because the larger pore sizes facilitated their movement (Fujimoto et al., 2010; Hodson et al., 2014).

The relative abundance of bacterial-feeding to fungalfeeding nematodes offers valuable insight into primary decomposition pathways in soil environments (Ferris \& Bongers, 2006). In general, fungal-feeding nematodes declined after year 1 regardless of fumigation treatment, 
probably because tilling during orchard establishment adversely affected fungal populations (Bailey et al., 2002). At Stanislaus, fumigation immediately decreased fungalfeeding nematodes. The Fungal Metabolic Footprint was 7.6 times higher in the controls compared to the fumigated plots and the relative abundance of fungal-feeding nematodes was still more than twice as high the following year. However, it is difficult to explain why this trend was not observed at Merced. Both sites had similar relative abundances of Aphelenchoides, but while Aphelenchus was observed at Stanislaus in year 1, it was not found at Merced until year 2. By contrast, bacterialfeeding nematodes increased over time for both treatments and sometimes responded positively to fumigation. Tillage also can increase bacterial populations and therefore favours increases in r-selected bacterial-feeding nematodes (Ettema \& Bongers, 1993). Fumigation may similarly increase bioavailable nutrients by facilitating release of $\mathrm{NH}_{4}{ }^{+} \mathrm{N}$ and phosphate from the soil, altering microbial communities (Rovira, 1976). The increased relative abundance of bacterial-feeding nematodes with fumigation at Stanislaus in year 2 could be partly due to these phenomena. This trend was due to an increased abundance of bacterial-feeding Acrobeloides, lending support to the hypothesis that this nematode could serve as an indicator of fumigation effects on bacterially-mediated decomposition (Sánchez-Moreno et al., 2010).

Fumigation effectively reduced plant-parasitic nematodes, with both sites showing immediate decreases in herbivorous nematode populations soon after fumigation as measured by the Herbivore Metabolic Footprint. The Plant Parasitic Index, which has been shown to be a useful measure of fumigation efficacy (Lenz \& Eisenbeis, 2000), was only higher in controls compared to fumigated plots in Merced in year 3 and no differences were seen at Stanislaus. However, at both sites the relative abundance of the pest species, Pratylenchus, remained low with fumigation.

\section{Conclusions}

Although multiple measurements within each year or larger sampling sizes may have revealed additional fluxes in nematode communities, this study shows that the effects of pre-plant fumigation in an orchard can persist for several years. It should be noted, also, that this study cannot separate the effects of fumigation from the effects of growing tree roots, since replicated plots were not included with bare soil and no trees. Applying fumigants markedly altered the composition of the nematode food web, reducing fungal feeders and predators, but increasing bacterial feeders at some time points. At both sites, the effects of fumigation, including reduced food web complexity due to loss of predators and sensitive taxa, were still apparent after 2 years.

\section{Acknowledgements}

We would like to thank Tony Rodin and another almond grower who allowed work in their orchard, Xuyun Yang for helping with nematode extraction and identification, and Minh Le, Katrina Joiner, Kisna Prado and Malina Loeher for lab assistance. This publication was supported by the U.S. Department of Agriculture's (USDA) Agricultural Marketing Service through Grant SCB15050. Its contents are solely the responsibility of the authors and do not necessarily represent the official views of the USDA. Support also came from California Department of Pesticide Regulation Grant 14-PML-R003.

\section{References}

Bailey, V.L., Smith, J.L. \& Bolton Jr, H. (2002). Fungal-tobacterial ratios in soils investigated for enhanced $\mathrm{C}$ sequestration. Soil Biology and Biochemistry 34, 997-1007. DOI: 10. 1016/S0038-0717(02)00033-0

Barker, K. (1984). Nematode extraction and bioassays. In: Barker, K.R., Carter, C.C. \& Sasser, J.N. (Eds). An advanced treatise on Meloidogyne. Volume 2. Methodology. Raleigh, NC, USA, North Carolina State University Graphics, pp. 19-35.

Bates, D., Mächler, M., Bolker, B.M. \& Walker, S.C. (2015). Fitting linear mixed-effects models using lme4. Journal of Statistical Software 67, 1-48. DOI: 10.18637/jss.v067.i01

Biagini, B. \& Zullini, A. (2008). Nematode communities in three differently managed agricultural fields. Fresenius Environmental Bulletin 17, 1151-1160.

Bongers, T. (1988). De nematoden van Nederland. Ern identificatietabel voor de in Nederland aangetroffen Zoetwateren bodembewunende nematoden. Wageningen, The Netherlands, Stichting Uitgeverij Koninklijke Nederlandse Natuurhistorische Vereniging.

Bongers, T. (1990). The maturity index: an ecological measure of environmental disturbance based on nematode species composition. Oecologia, 14-19. DOI: 10.1007/BF00324627

Bongers, T. \& Bongers, M. (1998). Functional diversity of nematodes. Applied Soil Ecology 10, 239-251. DOI: 10.1016/ S0929-1393(98)00123-1 
Bongers, T. \& Ferris, H. (1999). Nematode community structure as a bioindicator in environmental monitoring. Trends in Ecology \& Evolution 14, 224-228. DOI: 10.1016/S01695347(98)01583-3

Browne, G., Connell, J. \& Schneider, S. (2006). Almond replant disease and its management with alternative pre-plant soil fumigation treatments and rootstocks. Plant Disease 90, 869876. DOI: 10.1094/PD-90-0869

Collins, H.P., Alva, A., Boydston, R.A., Cochran, R.L., Hamm, P.B., McGuire, A. \& Riga, E. (2006). Soil microbial, fungal, and nematode responses to soil fumigation and cover crops under potato production. Biology and Fertility of Soils 1, 247257. DOI: $10.1007 / \mathrm{s} 00374-005-0022-0$

Culman, S.W., Snapp, S.S., Freeman, M.A., Schipanski, M.E., Beniston, J., Lal, R., Drinkwater, L.E., Franzluebbers, A.J., Glover, J.D. \& Grandy, A.S. et al. (2012). Permanganate oxidizable carbon reflects a processed soil fraction that is sensitive to management. Soil Science Society of America Journal 76, 494-504. DOI: 10.2136/sssaj2011.0286

Dungan, R.S., Ibekwe, A.M. \& Yates, S.R. (2003). Effect of propargyl bromide and 1,3-dichloropropene on microbial communities in an organically amended soil. FEMS Microbiology Ecology 43, 75-87. DOI: 10.1111/j.1574-6941.2003. tb01047.x

Ekschmitt, K., Bakonyi, G., Bongers, M., Bongers, T., Boström, S., Dogan, H., Harrison, A., Nagy, P., O’Donnell, A.G., Papatheodorou, E.M. et al. (2001). Nematode community structure as indicator of soil functioning in European grassland soils. European Journal of Soil Biology 37, 263-268. DOI: 10.1016/S1164-5563(01)01095-0

Eshel, G., Levy, G.J., Mingelgrin, U. \& Singer, M.J. (2004). Critical evaluation of the use of laser diffraction for particlesize distribution analysis. Soil Science Society of America Journal 68, 736-743. DOI: 10.2136/sssaj2004.7360

Ettema, C.H. (1998). Soil nematode diversity: species coexistence and ecosystem function. Journal of Nematology 30, 159-169.

Ettema, C.H. \& Bongers, T. (1993). Characterization of nematode colonization and succession in disturbed soil using the Maturity Index. Biology and Fertility of Soils 16, 79-85. DOI: 10.1007/BF00369407

Ferris, H. (2010). Form and function: metabolic footprints of nematodes in the soil food web. European Journal of Soil Biology 46, 97-104. DOI: 10.1016/j.ejsobi.2010.01.003

Ferris, H. \& Bongers, T. (2006). Nematode indicators of organic enrichment. Journal of Nematology 38, 3-12.

Ferris, H. \& Matute, M.M. (2003). Structural and functional succession in the nematode fauna of a soil food web. Applied Soil Ecology 23, 93-110. DOI: 10.1016/S09291393(03)00044-1

Ferris, H., Venette, R.C. \& Lau, S.S. (1996). Dynamics of nematode communities in tomatoes grown in conventional and organic farming systems, and their impact on soil fertility. Applied Soil Ecology 3, 161-175. DOI: 10.1016/ 0929-1393(95)00071-2
Ferris, H., Bongers, T. \& de Goede, R.G.M. (2001). A framework for soil food web diagnostics: extension of the nematode faunal analysis concept. Applied Soil Ecology 18, 13-29. DOI: 10.1016/S0929-1393(01)00152-4

Ferris, H., Griffiths, B.S., Porazinska, D.L., Powers, T.O., Wang, K. \& Tenuta, M. (2012). Reflections on plant and soil nematode ecology: past, present and future. Journal of Nematology 44, 115-126.

Flint, M.L. (2002). Integrated pest management for almonds, 2nd edition. Oakland, CA, USA, University of California, Division of Agriculture and Natural Resources.

Fujimoto, T., Hasegawa, S., Otobe, K. \& Mizukubo, T. (2010). The effect of soil water flow and soil properties on the motility of second-stage juveniles of the root-knot nematode (Meloidogyne incognita). Soil Biology and Biochemistry 42, 1065-1072. DOI: 10.1016/j.soilbio.2010.03.003

Gan, J., Yates, S.R., Crowley, D. \& Becker, J.O. (1998). Acceleration of 1,3-dichloropropene degradation by organic amendments and potential application for emissions reduction. Journal of Environmental Quality 27, 408-414. DOI: 10.2134/ jeq1998.00472425002700020023x

Griffiths, B.S., Daniell, T.J., Donn, S. \& Neilson, R. (2011). Bioindication potential of using molecular characterisation of the nematode community: response to soil tillage. European Journal of Soil Biology 49, 92-97. DOI: 10.1016/j.ejsobi. 2011.09.002

Hodson, A.K., Ferris, H., Hollander, A.D. \& Jackson, L.E. (2014). Nematode food webs associated with native perennial plant species and soil nutrient pools in California riparian oak woodlands. Geoderma 228-229, 182-191. DOI: 10.1016/ j.geoderma.2013.07.021

Hothorn, T., Bretz, F. \& Westfall, P. (2008). Simultaneous inference in general parametric models. Biometrical Journal 50, 346-363. DOI: 10.1002/bimj.200810425

Ibekwe, A.M. (2004). Effects of fumigants on non-target organisms in soils. In: Sparks, D. (Ed.). Advances in agronomy. San Diego, CA, USA, Academic Press, pp. 1-35.

Kapp, C., Storey, S.G. \& Malan, A.P. (2013). Options for soil health measurement in vineyards and deciduous fruit orchards, with special reference to nematodes. South African Journal of Enology and Viticulture 34, 272-280. DOI: 10. 21548/34-2-1105

Kuznetsova, A., Brockhoff, P.B. \& Christensen, R.H.B. (2017). lmerTest package: tests in linear mixed effects models. Journal of Statistical Software 82, 1-26. DOI: 10.18637/jss. v082.i13

Lembright, H. (1990). Soil fumigation: principles and application technology. Journal of Nematology 22, 632-644.

Lenz, R. \& Eisenbeis, G. (2000). Short-term effects of different tillage in a sustainable farming system on nematode community structure. Biology and Fertility of Soils 31, 237-244. DOI: 10.1007/s003740050651

Margenot, A.J. \& Hodson, A.K. (2016). Relationships between labile soil organic matter and nematode communities in a 
California oak woodland. Nematology 18, 1231-1245. DOI: 10.1163/15685411-00003027

Marks, T. (2016). Risk managment directive and mitigation guidance for cancer risk from 1,3-dichlorpropene (1,3-D). Sacramento, CA, USA, California Department of Pesticide Regulation. https://www.cdpr.ca.gov/docs/whs/pdf/1,3d_directive_mitigation.pdf.

Micke, W. (1996). Almond production manual. Oakland, CA, USA, University of California, Division of Agriculture and Natural Resources.

Neher, D. (2001). Role of nematodes in soil health and their use as indicators. Journal of Nematology 33, 161-168.

Okada, H. \& Kadota, I. (2003). Host status of 10 fungal isolates for two nematode species, Filenchus misellus and Aphelenchus avenae. Soil Biology and Biochemistry 35, 1601-1607. DOI: 10.1016/j.soilbio.2003.08.004

Okada, H., Tsukiboshi, T. \& Kadota, I. (2002). Mycetophagy in Filenchus misellus (Andrássy, 1958) Raski \& Geraert, 1987 (Nematoda: Tylenchidae), with notes on its morphology. $\mathrm{Ne}$ matology 4, 795-801. DOI: 10.1163/156854102760402586

Okada, H., Harada, H. \& Kadota, I. (2005). Fungal-feeding habits of six nematode isolates in the genus Filenchus. Soil Biology and Biochemistry 37, 1113-1120. DOI: 10.1016/j. soilbio.2004.11.010

Oksanen, A.J., Blanchet, F.G., Friendly, M., Kindt, R., Legendre, P., McGlinn, D., Minchin, P.R., O'Hara, R.B., Simpson, G.L., Solymos, P. et al. (2018). R package "vegan". https://cran.rproject.org/web/packages/vegan/vegan.pdf.

$\mathrm{R}$ Development Core Team (2014). R: a language and environment for statistical computing. Vienna, Austria, R Foundation for Statistical Computing. Available online at https://cran.rproject.org/.

Ritz, K., Black, H.I.J., Campbell, C.D., Harris, J.A. \& Wood, C. (2009). Selecting biological indicators for monitoring soils: a framework for balancing scientific opinion to assist policy development. Ecological Indicators 9, 1212-1221. DOI: 10. 1016/j.ecolind.2009.02.009

Rovira, A. (1976). Studies on soil fumigation-I: effects on ammonium, nitrate and phosphate in soil and on the growth, nutrition and yield of wheat. Soil Biology and Biochemistry 8, 241-247. DOI: 10.1016/0038-0717(76)90051-1

Sánchez-Moreno, S., Minoshima, H., Ferris, H. \& Jackson, L.E. (2006). Linking soil properties and nematode community composition: effects of soil management on soil food webs. Nematology 8, 703-715. DOI: 10.1163/ 156854106778877857
Sánchez-Moreno, S., Nicola, N.L., Ferris, H. \& Zalom, F.G. (2009). Effects of agricultural management on nematodemite assemblages: soil food web indices as predictors of mite community composition. Applied Soil Ecology 41, 107-117. DOI: 10.1016/j.apsoil.2008.09.004

Sánchez-Moreno, S., Jiménez, L., Alonso-Prados, J.L. \& García-Baudín, J.M. (2010). Nematodes as indicators of fumigant effects on soil food webs in strawberry crops in Southern Spain. Ecological Indicators 10, 148-156. DOI: 10.1016/ j.ecolind.2009.04.010

Shurtleff, M.C. \& Averre, C.W. (2000). Diagnosing plant diseases caused by nematodes. St. Paul, MN, USA, The American Phytopathological Society Press.

Sieriebriennikov, B., Ferris, H. \& de Goede, R.G.M. (2014). NINJA: an automated calculation system for nematode-based biological monitoring. European Journal of Soil Biology Short communication 61, 90-93. DOI: 10.1016/j.ejsobi.2014. 02.004

Small, G.J. (2008). The soil ecotoxicology of 1,3-dichloropropene under commercial growing conditions. Communications in Agricultural and Applied Biological Sciences 73, 777-785.

Stromberger, M.E., Klose, S., Ajwa, H., Trout, T. \& Fennimore, S. (2005). Microbial populations and enzyme activities in soils fumigated with methyl bromide alternatives. Soil Science Society of America Journal 69, 1987-1999. DOI: 10. 2136/sssaj2005.0076

Timper, P., Davis, R., Jagdale, G. \& Herbert, J. (2012). Resiliency of a nematode community and suppressive service to tillage and nematicide application. Applied Soil Ecology 59, 48-59. DOI: 10.1016/j.apsoil.2012.04.001

Wall, J.W., Skene, K.R. \& Neilson, R. (2002). Nematode community and trophic structure along a sand dune succession. Biology and Fertility of Soils 35, 293-301. DOI: 10.1007/ s00374-002-0478-0

Yeates, G.W., Bamforth, S.S., Ross, D.J., Tate, K.R. \& Sparling, G.P. (1991). Recolonization of methyl bromide sterilized soils under four different field conditions. Biology and Fertility of Soils 11, 181-189. DOI: 10.1007/BF00335765

Yeates, G.W., Bongers, T., De Goede, R. \& Freckman, D. (1993). Feeding habits in soil nematode families and generaan outline for soil ecologists. Journal of Nematology 25, 315331. 
Supplementary Table S1. Median relative abundance of nematode taxa (l soil $)^{-1}$ identified from fumigated (F) plots and controls (C) from sites in Merced County, CA, USA and Stanislaus County, CA, USA, their associated feeding groups and life history coloniser persister $(\mathrm{Cp})$ values.

\begin{tabular}{|c|c|c|c|c|c|c|c|c|}
\hline \multirow[t]{2}{*}{ Nematode taxa } & \multirow[t]{2}{*}{ Feeding group } & \multirow[t]{2}{*}{$\mathrm{Cp}$} & \multicolumn{2}{|c|}{2014} & \multicolumn{2}{|c|}{2015} & \multicolumn{2}{|c|}{2016} \\
\hline & & & $\mathrm{C}$ & $\mathrm{F}$ & $\mathrm{C}$ & $\mathrm{F}$ & $\mathrm{C}$ & $\mathrm{F}$ \\
\hline \multicolumn{9}{|c|}{ Merced County, CA, USA } \\
\hline Panagrolaimus & $\mathrm{b}$ & 1 & 0.0 & 0.0 & 0.0 & 3.8 & 4.5 & 2.8 \\
\hline Rhabditis & $\mathrm{b}$ & 1 & 4.9 & 20.2 & 4.4 & 0.0 & 6.8 & 8.4 \\
\hline Cephalobus & $\mathrm{b}$ & 2 & 1.3 & 0.5 & 0.0 & 0.0 & 28.2 & 19.3 \\
\hline Acrobeles & $\mathrm{b}$ & 2 & 0.0 & 0.0 & 2.2 & 1.6 & 4.9 & 2.0 \\
\hline Acrobeloides & $\mathrm{b}$ & 2 & 5.8 & 2.7 & 37.5 & 55.0 & 0.0 & 0.0 \\
\hline Prismatolaimus & $\mathrm{b}$ & 3 & 0.0 & 0.0 & 0.0 & 0.0 & 12.1 & 3.0 \\
\hline Aphelenchoides & $\mathrm{f}$ & 2 & 28.4 & 37.5 & 0.0 & 0.0 & 9.6 & 4.0 \\
\hline Aphelenchus & $\mathrm{f}$ & 2 & 0.0 & 0.0 & 2.2 & 2.5 & 5.4 & 2.0 \\
\hline Tylenchidae & $\mathrm{h}$ & 2 & 6.2 & $1.8^{*}$ & 13.6 & 2.7 & 11.2 & 17.8 \\
\hline Paraylenchus & $\mathrm{h}$ & 2 & 0.0 & 0.0 & 0.0 & 0.0 & 3.8 & $0.0^{*}$ \\
\hline Pratylenchus & $\mathrm{h}$ & 3 & 0.0 & 0.0 & 0.0 & 0.0 & 1.3 & $0.0^{*}$ \\
\hline Meloidogyne & $\mathrm{h}$ & 3 & 0.0 & 0.0 & 5.2 & 0.0 & 0.0 & 0.0 \\
\hline Trichodorus & $\mathrm{h}$ & 4 & 0.0 & 0.0 & 2.2 & 0.0 & 0.0 & 0.0 \\
\hline Mesodorylaimus & o & 4 & 0.7 & 0.0 & 0.0 & 0.0 & 0.0 & 0.0 \\
\hline Mononchidae & $\mathrm{p}$ & 5 & 0.0 & 0.0 & 0.0 & 0.0 & 5.5 & $0.0^{*}$ \\
\hline \multicolumn{9}{|c|}{ Stanislaus County, CA, USA } \\
\hline Panagrolaimus & $\mathrm{b}$ & 1 & 1.4 & 0.0 & 1.1 & 5.0 & 5.1 & 5.6 \\
\hline Rhabditis & $\mathrm{b}$ & 1 & 4.5 & 9.6 & 1.7 & 11.2 & 4.1 & 3.2 \\
\hline Cephalobus & $\mathrm{b}$ & 2 & 7.0 & 3.6 & 4.9 & 3.0 & 16.4 & 13.3 \\
\hline Eucephalobus & $\mathrm{b}$ & 2 & 0.0 & 0.0 & 1.5 & 1.4 & 0.0 & 0.0 \\
\hline Acrobeles & $\mathrm{b}$ & 2 & 0.0 & 0.0 & 5.8 & 2.1 & 4.9 & 7.4 \\
\hline Acrobeloides & $\mathrm{b}$ & 2 & 14.7 & 23.3 & 44.4 & $61.0^{*}$ & 1.2 & 2.5 \\
\hline Prismatolaimus & $\mathrm{b}$ & 3 & 0.0 & 0.0 & 1.0 & 0.5 & 10.0 & $2.0^{*}$ \\
\hline Aphelenchoides & $\mathrm{f}$ & 2 & 58.7 & 34.9 & 4.3 & 1.4 & 12.1 & 17.4 \\
\hline Aphelenchus & $\mathrm{f}$ & 2 & 2.9 & 2.3 & 8.8 & 2.9 & 2.3 & 1.2 \\
\hline Tylenchidae & $\mathrm{h}$ & 2 & 4.2 & 2.6 & 6.4 & 1.6 & 4.6 & 6.5 \\
\hline Paraylenchus & $\mathrm{h}$ & 2 & 0.0 & 0.0 & 2.0 & 1.5 & 14.4 & 18.4 \\
\hline Tylenchorhynchus & $\mathrm{h}$ & 3 & 0.0 & 0.0 & 0.0 & 0.0 & 4.2 & 4.4 \\
\hline Pratylenchus & $\mathrm{h}$ & 3 & 0.0 & 0.0 & 0.0 & 0.0 & 11.7 & $0.5^{*}$ \\
\hline Mesocriconema & $\mathrm{h}$ & 3 & 1.0 & 0.0 & 0.0 & 0.0 & 0.0 & 0.0 \\
\hline Xiphinema & $\mathrm{h}$ & 5 & 0.0 & 0.0 & 0.0 & 0.0 & 0.6 & 1.9 \\
\hline Qudsianematidae & o & 4 & 0.0 & 0.0 & 0.0 & 0.0 & 0.6 & 4.2 \\
\hline Mesodorylaimus & o & 4 & 0.0 & 0.0 & 0.4 & 0.0 & 1.5 & 6.7 \\
\hline Microdorylaimus & o & 4 & 0.0 & 0.0 & 0.9 & 0.0 & 0.0 & 0.0 \\
\hline Discolaimus & $\mathrm{p}$ & 5 & 0.0 & 0.0 & 0.0 & 0.0 & 0.2 & 0.1 \\
\hline
\end{tabular}

Asterisks denote statistical differences of $P<0.05$ by Kruskal-Wallace rank sum test. $\mathrm{b}=$ bacterial feeders; $\mathrm{f}=$ fungal feeders; $\mathrm{h}=$ herbivores; $\mathrm{o}=$ omnivores; $\mathrm{p}=$ predators. 